\title{
Reading Project Society in the Landscape
}

\author{
Sierra Leone, 2018-2012
}

\author{
Diana Szántó \\ Artemisszio Foundation, Budapest
}

\begin{abstract}
The paper proposes a short reflection on the nature of the post war political transformation in Sierra Leone, taking the visual signs of the streets as a starting point. The author observed the post-conflict democratisation process over five years, between 2008 and 2012, and describes how reading the political slogans, bill boards and popular graffitis allowed her following the subtle socio-economic changes characterising the country. The underlying argument is that the largely externally led liberal peace building using foreign and local NGOs as engines of a deep social transformation was based on abstract promises that ultimately failed to realise. Without effectively changing people's lives, these abstract promises normalised a value system that prepared a capitalist take off but ten years after the end of the civil war capitalist development still worked only for a tiny minority, making many people doubt about the benevolent nature of globalisation.
\end{abstract}

Keywords: liberal peace, democratisation, project society, NGOs, Sierra Leone, urban landscape

\section{SIERRA LEONE, 2008-2009. ${ }^{1}$}

\section{Educated by the State}

At the international airport in Lungi, a life-size ad greets travellers with the following slogan: "Love Salone. Change your attitude for good." Forming the map of Sierra Leone, the poster is printed in the national colours and is undersigned by the "Attitudinal and Behavioural Change Secretariat". The message might as well serve as an introduction to the major themes of the post-war reconstruction process. It reflects the tone of the large-scale social experimentation undertaken by the state and its

\footnotetext{
${ }^{1}$ Research was conducted with the help of the Wenner-Gren Foundation. The research project was also supported by the National Merit Program [TÁMOP 4.2.4.A/2-11-1-2012-0001], financed by the European Union and co-financed by the European Social Fund.
} 
international donors, aimed at the overall transformation of Sierra Leonean society emerging from a ten year civil war. ${ }^{2}$

According to a widely accepted view, this heroic enterprise was made necessary by the total collapse of social infrastructure as a result of the armed conflict. Accordingly, the bulky corpus of NGO literature often portrays Sierra Leone as a "blank sheet" (ICG 2007), a society that has to be reconstructed from scratch. ${ }^{3}$ Not only do developers present the country as a vast social laboratory, but they also indicate prescribed changes, which are seen as necessarily cultural rather than political. The attitudinal change slogan implicitly blames Sierra Leoneans, making their "attitude", i.e. their culture responsible for the war and for underdevelopment. This is an extremely biased way of analysing the situation, completely omitting economic and political factors and the role of the international community in the explosion and escalation of violence.

Surprisingly, citizens adhere enthusiastically to this analysis and to the prescribed change. In everyday life, they express the same idea in their own way: whenever a car overtakes in a dangerous way, a politician is accused of corruption or whenever people start pushing each other in a queue, somebody is ready with the usual comment: "Wi na Salone we no lov wisef." This Krio sentence has a double meaning. It should be translated "people do not care for each other in Sierra Leone", but it could also mean "we, Sierra Leoneans, do not have love for ourselves". The word "love" stands here for a particular type of social relationship governed by mutual solidarity, responsibility for others, and sharing - the opposite of selfishness and greed, the two most common accusations against corrupt leaders. For Sierra Leoneans, it is clear that the present state of their country is the result of a moral squalor, hence the force of the slogan demanding attitudinal change, which capitalizes on the genuinely Sierra Leonean tendency to make sense of the things of life in terms of moral economy rather than political economy.

This moral penchant relieves the ruling class from taking direct responsibility for the state of the country, instead laying the blame on national character, harmful tradition or backward culture. The reference to "attitude" has the additional advantage of flattering the international community by containing blame within the country, making it unnecessary to speak about the global causes of inequality, which, according to all inside witnesses, contributed greatly - if not directly - to the war.

Consequently, the "attitudinal change" campaign has no opponent; it unites across socio-cultural and even national boundaries. However, this broad agreement is based on an illusion of consensus. In fact, if all the parties involved speak the same language, everyone

\footnotetext{
${ }^{2}$ The country went through one of the $20^{\text {th }}$ century's most brutal civil wars between 1991 and 2002 .

${ }^{3}$ The 2007 ICG paper summarizes the situation in the following way: Sierra Leone ranks $176^{\text {th }}$ out of 177 countries on the HDI scale (Human Development Index), the rate of youth unemployment is at $80 \%, 70 \%$ of the population lives below the poverty line, and $26 \%$ in extreme poverty. The perception that the state is corrupt has grown since the war. Transparency International downgraded the country from the $126^{\text {th }}$ to the $142^{\text {nd }}$ position in 2006 . Although this is the usual way for presenting Sierra Leone, especially in project documentation destined to convince donors, sometimes the blank sheet theory is contradicted by observations regarding the surprisingly intact character of the social fabric. In the cited ICG paper, for example, we find references to a research project funded in 2005 by the EU, which found a "very low level of violent crime". Some authors do not hesitate even to express admiration for what they see as the "remarkable resilience of ordinary Sierra Leoneans" (Bellows - Miguel 2009:1145).
} 
assigns a different meaning to the words, and consequently draws different conclusions. From the point of view of Western donors, the attitudinal change should probably begin with the dismantling of patrimonial networks which keep national leaders under an obligation to cater to their families and close supporters rather than serving their broad constituencies. For the political elite, citizens should give up their exaggerated demands and exercise selfdiscipline. For ordinary people, quite to the contrary, the powerful have to be reminded of their obligation to share: for the lay citizens regard the redistribution of wealth within limited (and localized) personal networks as totally normal. The problem for them is not that leaders are corrupt. It is rather that their chain of distribution is not adequately expanded. What the international community regards as corruption is a burdensome obligation for the elite, whereas the average citizen regards it as a moral duty. This approach is very different from the Western concept of corruption, based on the "Weberian stereotype of bureaucracy as a legal-rational organization" (SHORE 2005:131). The general approval given to the attitudinal change campaign is therefore based on a vast intercultural misunderstanding. Allowing different - even contradictory - translations to coexist makes it possible to emphasize common objectives while veiling opposing interests.

Successful translations are based on a "maximized agreement", which depends heavily on similarities among the "belief-and-desire networks" of the interlocutors (GRANDY 1973:440). When similarity is only apparent or partial, translation becomes a question of approximation, an effort to transfer representations expressing beliefs and desires "from one frame of reference to another", hoping that the representation does not lose its validity in the process (RoTTENBURG 2009:xxxi). I suspect that the success of the attitudinal change campaign is in reality based on bad translation, keeping apart, rather than bringing closer very different belief-and-desire networks. In political terms, however, "bad translation" pays off. It allows different ideas about the desirable future to co-exist side by side without overt conflict, thus avoiding social upheaval.

In the context of international development, the debate about the desirable future becomes one about the form of modernity to achieve. Modernity here is used as a status marker to distinguish certain societies from other not-so-modern ones (LATOUR 1993). As everyone would like to stand high on this status ladder, the desirability of modernity is not an issue for anyone (FERGUSON 2006); the question is not if Sierra Leoneans should have modernity or not, but rather what sort of modernity they should strive for. Highly divergent, but equally plausible - if not equally legitimate - ideas about the kind of modernity to be achieved produce what I would call parallel worlds: coexisting but distinct (and sometimes opposing) frames of reference.

The official frame-of reference - that of the liberal peace-building experiment in Sierra Leone - contains a social theory according to which the way to access the material benefits of modernity (better roads, fewer black-outs etc.) necessarily follows from a social process understood as democratization (NEwman et al. 2009). The second corollary of this theory is that effective democratization depends on the strength of civil society. The final logical step consists of equating civil society with the number of voluntary organizations or NGOs formally registered in a country (FELDMAN 1997). Although the chain of causality seems to be based on common sense, application of the theory for development is relatively new.

In the early days of international aid, the contrary was presumed. It was suggested that technological-economic development paved the way to democracy (ALLEN - 
Thomas 2000). This concept was the ideological foundation for many of the earlier developmental interventions, including the structural adjustment agenda of the IMF, practiced on a wide range of societies on different continents. By the 1990s, the failure of the structural adjustments became evident and the development frame proposed by the international community lost its credibility as well as its popularity (RENO 1996). A new form of development had to be invented: a development with a "human face". This change coincided with the end of the cold war, which left neoliberal capitalism as the only player in town. It followed that the issue for developing countries was no longer whether to build capitalism or not, but how to build it. The transformation of developmental thinking resulted in a growing interest in democratization, leading in turn to the gradual "dematerialization" of development objectives (SzÁNTó 2011), shifting from the erstwhile hegemonic concepts of "appropriate technology", "intensive agriculture" and "export orientation" (CREWE - HARRISON 1998); to more sophisticated development goals, such as "good governance", "the rule of law" and "transparency". It is in this historical context that the announced objective of attitudinal change takes on its full meaning.

My discovery of the giant poster in the shape of the Sierra Leonean map at Lungi airport was not the only time I was made to reflect on the use of strong visual signs to express complex moral and political ideas in post-war Sierra Leone. Such images were absolutely omnipresent and they seemed to fulfill the same educational purposes that stained glass cathedral windows served in the middle ages: to convey an entire moral system to the illiterate population through pictures. In the capital as well as in the provinces, the ideals of the new - modern and cosmopolitan - development regime were systematically presented for immediate consumption on political posters and sign boards, underlining the opposition with the value system to be overcome that was supposed to be local and traditional.

One of the billboards targeted gerontocracy by depicting an old man in a customary garment pointing his finger at the spectator in an accusative fashion, with the inscription: "You! Start listening to the voices of youth!" Another showed a well dressed woman in her office asking for "fifty-fifty", i.e. 50\% representation of women in politics. The essence of the message was that the time had come to reject the system of patriarchy and gerontocracy and transfer power to young people and women. In this new philosophy, the identity marker of being young and female was immediately imbued with symbolic capital, at least in theory. Youth (a category of persons, which, at the same time, was not easy to dissociate from that of the perpetrators of atrocities in the war) and women (some of whom were also ex-combatants) effectively became the two favourite target groups of democratization through civil society building, which made members belonging to (or classified as belonging to) these categories extremely vulnerable to co-optation by the powers that be. While the use of this rhetoric did in effect help some women to achieve leading positions in politics and civil society, it was difficult to see how effectively the new regime addressed the most burning concerns of youth - male and female alike: inadequate education, unemployment and poverty.

Another poster admonished policemen to participate in the fight against HIV with the following words: "the force of good uses condoms". A third one is addressed to careless parents, urging them to send their "girl child to school". One publicity slogan seemed to draft a theory of social welfare, leaving the identity of the addressee unidentified: "we kopo no dae, well body no dae, i noto fo bi so" (when there is no money, there is no health - 
this should not be like this). Another image depicted a squatting man trying to hide behind a thin tree trunk, with the solemn warning: "There is no place for a corrupt man to hide."

The themes addressed by the posters were multiple and disparate, but their common thread was a call for individual responses in the face of broad structural problems: lack of education, lack of medical care, health threats, corruption. Read together, the messages of the posters drew the contours of a coherent value system - that of an enlightened, post-industrial liberal democracy based on the individual responsiveness of citizens.

Posters have a magical force: they not only fix targets, but by making them visible, they also paint an imaginary and desired society as one that almost exists already. There is no problem if the picture does not correspond to the daily experience of millions of Sierra Leoneans. Everyone knows that in real life corruption does exist and it is relatively easy to get away with it. Even the two top officials in the Attitudinal Change Secretariat had to be dismissed after being implicated in corruption cases that grew too noticeable. In fact, children often fail to attend school simply because their parents are unable to cope with the informal financial burden, even though education on the primary level is officially free. Badly paid teachers frequently require "fees" from students or simply sabotage the teaching process altogether, even registering students who physically never have to appear, in exchange of "gifts". In reality, schools are full of "ghost students" and even "ghost teachers". Consequently, while learning is costly for the students, the efficacy of the teaching is extremely low. Young children and pregnant women routinely die because without money they do not have access to hospitals, despite the newly introduced "free health care system", ${ }_{4}$ or even if they are admitted, they might still lack treatment. On one hand, there is the shiny poster-realty that depicts the country in a projected state of already - or at least nearly - achieved "development". On the other, there is real life, which systematically negates these idealistic images. Although everybody is aware of this delusion, very few would denounce it. Poster-reality is not seen as a lie, but as a projection of society's own self-reflection in an idealizing mirror.

\section{PROJECT SOCIETY}

It is not only the government that educates citizens through pictures. NGOs also use this channel to convey their messages. NGO publicity is coherent with overall political goals, but often translates these into specific project objectives. The overwhelming presence of projects, manifest in signs painted on walls, gates, posters, even on moving vehicles, is indeed the most striking feature of the country for a newly arriving visitor in 2008. The rapid decay of the signboards by the roads shows that projects are constantly born, but then quickly die. As a result, the countryside resembles less a burgeoning worksite than a

\footnotetext{
${ }^{4}$ The "Free Health Care System" was introduced in 2010 at the instigation of UNICEF, which remains its main funder. The system aims at providing free hospital admittance and treatment to pregnant women, nursing mothers and children under five years of age. The scheme has resulted in undeniable achievements, but its implementation is not without problems. In 2011, the notorious disappearance of "free health care drugs" was a regular topic in urban gossip. The biggest scandal broke out when two boats full of drugs were discovered in the port of Freetown the night before they would have sailed for neighboring Guinea.
} 
vast cemetery of defunct projects. Some traces are left behind: schools or hospitals were constructed (which does not necessarily mean they still function), but many of them publicize more subtle results: "empowerment", "sensitization" and "awareness raising" - in conformity with the general trend of the "immaterialization" of development aims.

One dusty bill-board set up at the entrance of a village, for example, advertised an entire list of projects: "Access to Justice", "Conflict Transformation and Prevention", "Human Rights Monitoring", "Empowerment of Youth and Women", "Adult Literacy", "Skills Training and Income Generation", "Community Management and the Power Relation Process". The particularity of this list is, of course, its language, which makes it impossible to understand what exactly happened here. Such blurring comes about through the use of "buzz words", i.e. typical discourses" (ANGÉ 2009; CORNWALL 2007), which perform a "magical" function in as much as they create the very world they are supposed to describe. In this way, they reveal much less about what they are indexed to in real life than about the social universe in which they are to be interpreted.

Sampson calls this universe of meaning "Project Society" (SAMPSON 2005). Although the term was first used to describe a time-specific social reality in the Balkans related to the institutionalized fight against corruption, its application can be generalized and extended. It seems to suit the case of Sierra Leone perfectly. Sampson defines "Project society" as a system combining certain types of activities, a specific structure and a relation system between different social roles, the main function of which is to organize redistribution.

\footnotetext{
"'Project society' entails a special kind of activity: short term activities with a budget and a time schedule. Projects always end, ostensibly to be replaced by policy, but normally to be replaced by yet another project. Project society entails a special kind of structure, beginning with the donor, the project identification mission, the selection of an implementing partner, the disbursement of funds, the monitoring, the evaluation and of course, the next project. Project society is about the allocation of resources in an organized, at times bureaucratic way." (SAMPSON 2005:121)
}

Projects are not isolated, individual actions. They take place in a complicated network, in which different categories of actors carry out specific tasks. This is why the signboard cited above is undersigned by a number of agents: "Supported by the European Commission", "European Initiative for Democracy and Human Rights" through "Christian Aid UK". This enumeration gives quite an adequate hint of how the system works. In order for a project to exist at all, first a "donor" is needed - in general a foreign (Western) agency, or a transnational entity, in this case the European Commission. The "European Initiative for Democracy and Human Rights" is the financing instrument whose role is to channel the resources from the donor to the implementer. The financing instrument presupposes the existence of a particular type of implementer: an international organization or NGO (non-governmental organization). ${ }^{5}$ In this particular case, Christian Aid UK apparently

\footnotetext{
${ }^{5}$ Created by an initiative of the European Parliament in 1994, the European Initiative for Democracy and Human Rights (EIDHR) grouped together budget headings for the promotion of human rights, democratization and conflict prevention, which generally had to be implemented in partnership with non-governmental organisations (NGOs) and international organisations. http://europa.eu/ legislation_summaries/human_rights/human_rights_in_third_countries/r10110_en.htm (accessed January 15,2012 )
} 
implemented the project(s) directly, but it is possible that a local NGO was switched in the system. The final destination of the project, the last point in the chain, is the "target group" or the group of "beneficiaries" - usually confounded by a "local community".

In post-war Sierra Leone, projects are omnipresent because they constitute the dominant redistribution system through which resources are allocated to hierarchized objectives, within the framework of Project Society. In this framework, it is not only NGOs that may become intermediary recipient organizations responsible for redistribution, but also the State itself. Inevitably, donors within this system of exchange have a higher position than recipients - in accordance with the exchange theory of Mauss and Levi-Strauss (MAuss, 1954; LÉVI-STRAUSS 1969). As a recipient, the state - as with smaller organizations - is controlled by donors, and when the state acts as a re-distributor, it also controls others recipients. The homology of the position occupied by the State and NGOs as recipients explains the similarity between the idiom of state ideology and that of NGO language. In other words, it shows the dependency of the state on foreign donors.

This dependency is not only technical, but largely cultural. Through the projects, money as well as technical and human resources are channelled from higher hierarchical levels to lower ones. Through buzz words and political slogans, ideas, norms and values are simultaneously transferred in the same direction. This special linking of economic and cultural capital turns Project Society into a specific type of governmentality in a Foucauldian sense. In Foucault's view, governmentality is a particular set of techniques and rationalities by which "a society is rendered governable" (MAYHEw 2004). Saying that NGOs participate in governing does not necessarily mean sharing the criticism which accuses NGOs of directly serving the neo-liberal agenda (FeLDMAN 1997), but it effectively implies that the chain in which NGO operations become meaningful in Project Society is necessarily a part of the power structure. Ironically, donors who also recognize this connection, somewhat resentfully, often lament about the "donor-driven" nature of Sierra Leonean development.

\section{SIERRA LEONE, 2011-2012.}

\section{Popular appropriation of project society}

The power structure in which NGOs participate is necessarily one of a hegemonic kind in a Gramscian sense (GRAMSCI - BUTTIGIEG 1992), which means that its efficacy largely depends on the subjects' appropriation of and identification with its norms. In Sierra Leone, evidence of this collective adherence to the state's value system is reflected in graffitis and popular inscriptions that are often painted on selling stands, ordinary buildings or on standing stones. These messages seem to respond to the political agenda with an enthusiastic approval. One street vendor celebrated the $50^{\text {th }}$ anniversary of independence by painting the following message on his wooden tobacco stand: "Motto: Agenda for change $-50^{\text {th }}$ Anniversary"; and at Lakka beach, a restaurant owner decorated his kitchen with a solemn incantation: "Sierra Leoneans! Love one another!" To this call responds the inscription on a bodega introducing itself as the "Peace and Love Telecenter", or the inscription on an urban fence, which reads "Welcome to the base of S.T.C. Social Club. To unite is our pride." 
These messages speak about love, unity and peace - probably fed by the natural instinct of a people which has just emerged from a terrible war. At the same time, it is striking how these popular slogans are in conformity with dominant discourses of state policies. Such apparently humble adherence to the official ideology is, however, mitigated by the inherent ambiguity of the slogans themselves. While the "Agenda for change" is the official development plan of the Sierra Leonean government, the urgent call for necessary change could be interpreted as bold social criticism as well. Urging for "love" - as we have seen - may be read as a claim for a more equitable and just sharing. The call to "unite" certainly corresponds to the nationalist project of the state, but it is also the last resort of the oppressed. All of these inscriptions are (in all likelihood unconsciously) doubleedged, but what is remarkable is that even their potential for subversion is expressed in the idiom of the dominant system - as if it were indeed impossible to talk outside of it.

This self-imposition of a certain language is achieved by its omnipresence, which makes it the daily experience of people. Repetition creates the sense of normalcy and routinized practices and taken for granted discourses assure that project society is experienced not so much as a disciplinary mechanism, but rather as a shared life/world, with all its banality. What Scheper-Hughes - referring to Gramsci - establishes in her description of another poor society in the North of Brazil seems to remain valid here:

\begin{abstract}
"Gramsci realised that the dominant classes exercise (d) their power both directly through the state and indirectly through a merging with civil society and identification of interest with broad cultural ideas and aims (...). It is through this blend of instrumental force and the expressive, contradictory (but also consensual) common sense of every day culture that hegemony operates as a hybrid of coercion and consensus." (SCHEPER-Hughes 1992:171)
\end{abstract}

What traditional intellectuals are to Gramsci and the technicians of the modern bureaucratic state are to Scheper-Hughes, it is what the NGO elite is to Project Society, its role being "to sustain common sense definitions of reality through their highly specialised and validating forms of discourse" (SCHEPER-HUGHES 1992:171).

On a planetary scale, the social and cultural distance between the hegemonic elite and the subaltern was once reproduced in the hierarchical distance established in the opposition of developed versus developing nations. It was those belonging to the first group who had the power to produce the "common sense definitions of reality" for the second group. Today, the somewhat obsolete "developed - underdeveloped" dichotomy tends to be replaced by the "global - local" opposition, ${ }^{6}$ which in spite of its apparent power neutrality, has inherited the implications of inequality based on an old pattern, that of the global diffusion of a Western worldview (RotTENBURG 2009:xii). Crewe and Harrison (1998) go to great lengths to list the main characteristics of this worldview, symbolically embodied by the figure of what - after Nancy Folbre - is referred to as the REM, or the Rational Economic

\footnotetext{
${ }^{6}$ Ferguson points at the ethnocentrism of the expression, usually implying a planetary network of connected points, one that "Africa" is marginal to (FerGusOn 2006:6). By exploiting the dichotomy, I certainly do not wish to suggest that Africa is not part of the global, whatever the latter might be. Like any other local point, Africa, including Sierra Leone, and the world viewed from any point of reference - for example from Sierra Leone - looks like a web of foreign influences. It is from this emic perspective that I use the world "global".
} 
Man. The REM, a human committed to individualism, humanism and rationalism, not only represents an ideal self-image of the West, but has also been transformed into the ideal recipient of development projects (CREWE - HARRISON 1998:40).

\footnotetext{
"Arguably, reforms within the development industry remain entangled in the principles and ideas upon which it was founded. These include a series of related assumptions, with their origin in European Enlightenment, in which rationality, the search for objective truth and a belief in a movement towards modernity are paramount." (CREWE - HARRISON 1998:15)
}

In West Africa, this statement still holds, albeit in some self-contradictory way. In the changing political and economic landscape, the impact of other, non-Western powers and organizations - and consequently world views - is constantly increasing. Sierra Leone's membership in the African Union, the Economic Community of West African States and the Mano River Union is only the official façade of this non-Western alignment, but influences linked to economic participation - Arabic, Chinese, Brazilian and Indian - also play an important role. Nevertheless, while economic power is increasingly multicontinental, the institutional system of Sierra Leonean Project Society is still dominated by a concept of the global which is synonymous with Western, and for which "local" is another word for "traditional", while "modern" is used as an exclusive self-identification by donors with Western headquarters.

The occupation of this twice winning - global and modern - position, endows Project Society with a universal value. Universality is non-questionable by definition as there is no legitimate point from which it could be questioned. It is a meta-position, placing itself above all localizable positions, denying its own localized origins. The messages of Project Society are written in a "meta-code", a universal code that boasts to fit all frames of reference (ROTTENBURG 2009:xxix) while not being totally valid in any of the actually existing cultural contexts. Because "transparency", "the rule of law", and "good governance" do not really exist as models that can simply be transferred from one geographical zone to another, they are rather labels for idealized practices that nowhere exist full-fledged in the real world. Consequently, it is not Western modernity that is being transferred, but its own idealized self-image. The encounter is not between two cultures, but between one meta-code and various cultural codes, between the existing life world of Project Society and different pre-existing cultural worlds.

The "othering" aspect of Project Society is not only a specific framing mechanism; it also penetrates everyday relations. Within the hierarchy created in this way, higher social status, economic power and proximity to the "international community" are merged together on one side. At the top of the social hierarchy sit the experts, office holders and diplomats of bilateral and multilateral donor organizations, and just below them are the experts and technicians of international NGOs, two categories lumped together under the common denomination of "expatriates". 7 In theory, the term simply means a

\footnotetext{
${ }^{7}$ It is to be reminded that the analysis proposed here is highly contextualised. It is precisely located in place and time. The situation is quickly changing and what was true for the Sierra Leonean society in 2010 is by no means valid today. Also in Sierra Leone the relation between the State and civil society has become more conflictual and the poltical elite often express their refusal of this hierarchy.
} 
workforce acting locally on the account of a foreign employer; in practice it connotes an entire organizational field as well as a special place within it, with serious consequences for the social value of individuals. Expatriate then becomes a somewhat racially tainted status definition. ${ }^{8}$ It is not that all expatriates are white, but expatriates logically come from more developed countries, and whatever the economic reality is today, Europe and North America still stand as models for development. Consequently in local minds there is a conflation between whiteness and the status of the expatriate. Even black NGO workers are shouted after, children calling them "pumuy", or "opoto", the informal form of address reserved to white people.

In the ranking order expatriates are followed by members of the local political elite and the elite of the local NGO world - two categories which frequently are also merged and both of which are linked in various ways to international agencies. In principle, there is no place in this system for representatives of the traditional order (for example chiefs and paramount chiefs), and in Freetown they do indeed seem to be absent from Project Society. Even so, in the countryside it is easier to realize that the boundaries between the traditional elite, the political elite and NGO elite are equally fuzzy. This seems to confirm Bayart's theses on the "reciprocal assimilation of the elites" (BAYART 1993).

At the bottom of this hierarchy is the local community: an undifferentiated pool of Sierra Leoneans simultaneously providing both the target group and the human context for Project Society. On this level, a new terminological opposition is created between "civil society" and "local community". In its broadest sense, civil society could simply mean a group of civilians constituting a community, sharing - and representing - collective interests and values, but the fact that the bureaucratically organized NGO world has practically expropriated the expression facilitates the demarcation between what belongs and what does not belong to civil society, placing "democracy" on one side and "culture" on the other. In this particular scenario, an officially registered one-man organization with no other agenda than getting a slice of the big cake distributed by bigger NGOs would be listed as a proof of an existing democracy. In contrast, a female secret society responsible for mediating power within the local and national - essentially male - political leadership would be relegated to the domain of culture. Culture in this context is regarded as a dangerous link to tradition, obstructing the way to modernity, in spite of references to culture in political discourse as something that has to be protected. In everyday use, the term culture has become something much simpler. Street hustlers selling tourists cheap beads of wood and plastic offer their merchandise as "culture". Community is another term intimately linked to that of culture, and it is treated with the same ambiguity: sometimes as a threat, the very something to be changed, and sometimes as a supreme value and a justification for intervention, proving its embeddedness in the "grass-root".

In this complicated semantic field, dichotomies are generated by ramification, each newly invented term producing a new meaningful binary pair. The forest of public signboards and promotions also reflects this expanding nature of Project Society. Its dichotomizing, "othering" character is revealed in a picturesque way on one giant signboard exposed in the city centre of Kabala - certainly a relic originating from the early days of international engagement in the country. The picture shows a large jeep

\footnotetext{
${ }^{8}$ For an analysis of "the transformation of a social category into a self-recognizing and self-defined group" in the case of EU bureaucrats, see: SHORE 2005.
} 
with white people sitting in it and a few waving black soldiers on foot, trying in vain to get a lift. The inscription in Krio explains in a friendly manner: "Wi nor dae gi lift to fetman no to se wi hate una, na wi lo no dea permit wi fo do dat" (We cannot give rides to soldiers, not because we hate you, but because our law does not permit us to do so).

In fact, the internal regulations of NGOs are full of rules that function to separate locals and expatriates, arranging segregation on the basis of nationality. Differentiation of rights and duties appears as a cumbersome, but unavoidable bureaucratic necessity; a consequence of the inherent dangerousness of the local context. Even ten years after the end of the civil war, this philosophy has yet to change. Expatriates are protected by a series of rules, prohibiting them from getting around in town alone, from taking public transportation, from walking around after sunset, etc. The rules are obeyed with uneven zeal, but they are never contested openly. NGO jeeps and high electric fences are the external manifestation of this obsession with security. In a way, the rules of the NGO world haphazardly endorse a powerful theory sometimes expressed explicitly by political analysts and journalists who attribute the horrors of the civil war to the intrinsic barbarism of Africans (KAPLAN 1994). This type of analysis systematically underestimates the role of international actors in creating the violent social and economic situation which led to the armed conflict. In this perspective, local is not only linked to traditional but also to barbarous. It is no wonder that in such conditions changing attitudes becomes an imperative: it is the condition for the transformation of an ignorant brutal horde into a modern society of rational, enlightened, liberal democrats.

The Kabala sign-board may reveal an even more complex social reality. After all, it shows black people on foot unsuccessfully demanding help from white people in a car. I believe the picture also evokes an old theme in European (and also North American) social history: the fear of the poor. However understandable and justified NGO regulations are, the ironic self-contradiction inherent to the situation - rich (white) people protecting themselves from (black) poor people they have come to help - transcends the basically informative aspect of the sign board. The picture translates into a concrete situation the social and cultural hierarchy the reigning power structure produces - which, by the force of being presented as necessary and natural is becoming accepted by the population as: necessary and natural.

\section{BUILDING THE LIBERAL PEACE, BUILDING CAPITALISM}

Project society seemed to be monolithic and permanent when I first met it in Sierra Leone but over the years I observed it undergoing slight changes. Despite superficial resemblances, by 2012 Sierra Leoneans lived in a very different world as compared to 2008. In 2012 the slightest improvement of life was still only an unreachable dream for most people, but development started to be actually visible in the street.

I remember back in 2008 I was once contemplating the traffic on a major street from a terrace and suddenly became aware that practically all the big jeeps passing were NGO vehicles. It was really as if NGOs had been taking over the power. By 2012, the traffic jam on Saturday night in the more residential west side of town had become at least as unbearable as the one in downtown Paris. Many vehicles were still undoubtedly driven by expatriates, but to all likelihood many cars were owned by locals. Wherever one looked, 
immense and beautiful new buildings were growing out of the dusty and heteroclite urban landscape. As the most blatant emblems of the new society under construction, two giant screens exposed at the two extremities of the city now shed bright light on the street, diffusing publicities and loud video clips to the greatest joy of passers-by used to the darkness of frequent power cuts. The contrast between the bright, trendy pictures and the chaotic and obscure street scene is striking. Economic development is unquestionable, but even visually, it is limited to isolated islands within a sea of still ambient and no less ostensible mass poverty.

By 2012, the visual education of the people through posters, sign boards and painted slogans was reinforced by a new genre: that of commercial publicities. Just like their predecessors, these also came to shape the imagination and project the desirable future. Their ever increasing presence and growing importance in the urban landscape testify to a new, still embryonic, but clearly visible and rapidly expanding capitalist form of development.

Contrary to what might be expected, the new capitalist-consumerist city does not supplant Project Society. The latter remains the main frame, easily accommodating the former. The same words can be used to build democracy and make fair profit. Buzz words of the NGO world have also entered business.

One new publicity warns: "It is time to protect our resources." It is indeed a reasonable message, taking into consideration what an important role the looting of the country's natural resources played in provoking the war. However, it soon becomes evident that the signboard is not calling upon the state to protect natural resources from foreign exploitation so much as instigating the man on the street to watch over "transparency and accountability". The message continues like this: "Join the effort to enforce transparency and accountability in the extractive sector - signed by the SL Extractive Industries Transparency Initiative." The irony of the message lies in the fact that it is public knowledge that "transparency" and "accountability" do not at all characterize either the foreign-owned companies that monopolize the mining sector or the state's policies towards them, which openly transgress its own legislation. ${ }^{9}$ What can the man in the street really do about this?

While their styles are certainly different, the publicities of the state, NGOs and companies resemble each other more than they diverge. All rely on the responsiveness of the individual, skilfully mixing moral pressure, conviction and seduction by projecting an idealized image presented as an achieved normalcy. The buzz words of the consumerist world may be "worth", "dream" or "improved living standard". These expressions are as abstract as "rule of law", "accountability" and transparency" - far from the reality experienced by the vast majority of the population. Nevertheless, they do "talk" to the people. When an ordinary pedestrian looks at the giant poster of the People's Bank showing a young woman playfully dancing amongst her newly acquired assets (a washing machine, a TV and a sofa), the impression created is not that the poster is lying about the

\footnotetext{
${ }^{9}$ The Mines and Minerals Act came into effect in 2009. It prescribes certain rules by which foreign mining companies are expected to share the benefits of their activities with the state and cooperate with local communities. And yet, practically none of the big mining companies abides fully with this law. The irregularities include excessive tax concessions, abnormally long extraction rights (one such contract gives the extraction right to the company for 100 years) and the harassment of local communities.
} 
average living standard of Sierra Leoneans. On the contrary, it suggests that this "living standard" is the norm, and any deviance from it is an individual tar. The visual message is reinforced by an explicit message: "Achieve your dream of improved living standard."

Material well-being has thus become a question of individual choice and personal achievement. Another sign, advertising PHB Bank, responds more directly to the call for "attitudinal change". It invites the onlooker with impressive simplicity: "Be you, be free, be brilliant!" Thus, the circle is closed and the relation established: The cultural revolution that was announced for the betterment of the country, demanding personal effort from each citizen to change his/her attitude, is expected to produce a new type of person, conscious of his/her personal uniqueness, freed from the chains of tradition and community - in other words, the perfect subject of a Western-type individualistic society. This is how the idealized world of state-designed social reform, the NGO world and the capitalist world blend and exist in harmony within Project Society.

This harmony is not completely flawless, however. Despite general optimism and faith in a better future - so surprising for an anxious European mind terrified by the perspective of crisis - the people of the street do not hesitate to express their dissatisfaction with certain facets of the transformations proposed to them. While the international character of the NGO world is acknowledged to be the necessary condition for the circulation of resources, not everybody buys into the idea of globalization as a benevolent magician freeing the individual and enriching the community. Ordinary citizens sense their exposure to global forces with much scepticism. The popular expression "we have the global", usually accompanied by an expressive gesture meaning "what can we do (?)", refers to the negative sides of globalization. People evoke it sarcastically when they want to talk about rising fuel and food prices or their own incapacity to acquire even the most basic goods.

This sarcasm also appears visually. The insignia on one sign-board of a small shop selling simple articles reads: "global needs shop". Two steps from there, a giant poster greets investors: "Welcome to the new gated-community of Grafton." The orderliness and luxury of the (still imaginary) new housing estate in the picture may indeed be the future, but this future proposes little relief to those who tomorrow, just like today, will queue up unwillingly in front of the "global needs shop". Project Society, despite all its internal contradictions, has begun to fulfill its promise in Sierra Leone, but if the expanding frontiers of capitalist development function as the walls of gated communities, pushing poverty - and the poor - farther and farther back to the hinterland of underdevelopment, would this not deepen the gap between the parallel worlds and after all give reason to those who have come to the conclusion: "wi na Salone wi no lov visef?"

\section{REFERENCES CITED}

Allen, Tim - Thomas, Alan

2000 Agencies of Development. In Allen, Tim - Thomas, Alan (eds) Poverty and Development into the $21^{\text {st }}$ Century, 189-218. Oxford - New York: Open University - Oxford University Press. 
AnGÉ, Olivia

2009 La circulation des vocables «fétiches» dans une association de petits producteurs andins [The Circulation of the Word "Fetishes" in an Association of Small Andean Producers]. Université Libre de Bruxelles, Centre d'Anthropologie Culturelle (unpublished).

BAYART, Jean-François

1993 The State in Africa. The Politics of the Belly. London - New York: Longman.

Bellows, John - Miguel, Edward

2009 War and Collective Action in Sierra Leone. Journal of Public Economics (93):1144-1157.

Cornwall, Andrea

2007 Buzzwords and Fuzzwords. Deconstructing Development Discourse. Development in Practice 17(4-5):471-484.

CREWE, Emma - Elizabeth HARrISON

1998 Whose Development? An Ethnography of Aid. London: Zed Books.

Feldman, Shelley

1997 NGOs and Civil Society. (Un)stated Contradictions. Annals of the American Academy of Politics and Social Science. The Role of NGOs: Charity and Empowerment 554:46-65.

FERGUSON, James

2006 Global Shadows. Africa in the Neoliberal World Order. Durham, N.C.: Duke University Press.

Gramsci, Antonio - Buttigieg, Joseph A.

1992 Prison Notebooks. New York: Columbia University Press.

GRANDY, Richard

1973 Reference, Meaning, and Belief. Journal of Philosophy 70(14):439-452.

INTERNATIONAL CRISIS GROUP

2007 Sierra Leone: the Election Opportunity. International Crisis Group.

KAPLAN, Robert D.

1994 The Coming Anarchy. How Scarcity, Crime, Overpopulation, Tribalism, and Disease Are Rapidly Destroying the Social Fabric of our Planet. Atlantic. February. http://www.theatlantic.com/magazine/archive/1994/02/the-cominganarchy/304670/ (accessed July 31, 2016)

LATOUR, Bruno

1993 We Have Never Been Modern. Harlow: Pearson Education.

LÉvi-Strauss, Claude

1969 The Elementary Structures of Kinship (Les Structures Élémentaires de la Parenté). London: Eyre \& Spottiswoode.

Mayhew, Susan

2004 Governmentality. In MAYHEw, Susan (ed) A Dictionary of Geography. Oxford: Oxford University Press.

Mauss, Marcel

1954 The Gift. Forms and Functions of Exchange in Archaic Societies. Glencoe, IL: Free Press. 
Newman, Edward - Paris, Roland - Richmond, Oliver P.

2009 New Perspectives on Liberal Peacebuilding. Tokyo - New York: United Nations University Press.

RENO, William

1996 Ironies of Post-Cold War Structural Adjustment in Sierra Leone. Review of African Political Economy 23(67):7-18.

RotTENBURG, Richard

2009 Far-Fetched Facts. A Parable of Development Aid. Cambridge, Mass.: The MIT Press.

SAMPSON, Steven

2005 Integrity Warriors. Global Morality and the Anticorruption Movement in the Balkans. In Haller, Dieter - Shore, Cris (eds) Corruption. Anthropological Perspectives, 103-130. London: Pluto Press.

SCHEPER-HugHes, Nancy

1992 Death without Weeping. The Violence of Everyday Life in Brazil. Berkeley: University of California Press.

SHORE, Cris

2005 Culture and Corruption in the EU. Reflections on Fraud, Nepotism and Cronyism in the European Commission. In Haller, Dieter - Shore, Cris (eds) Corruption. Anthropological Perspectives, 131-155. London: Pluto Press.

SzÁNTó, Diana

2011 A gyarmatosítástól a nemzetközi fejlesztésig: az észak - déli kapcsolatok történetének rövid áttekintése [East - West, North - South, Development and Underdevelopment. A Short History of Inequality]. Ethnographia (2):157-181.

Diana Szántó is the Director of Artemisszio Foundation, a private organisation promoting applied anthropology in Hungary. She did research in Amazonia, in Europe (France, Hungary) and West-Africa. Her research interest presently is in migration, urban anthropology, public health, civil society and state relations. She wrote her doctoral thesis on the disability movement in Sierra Leone, embedded in the post-war democratisation process following the 1991-2002 civil war. Email-address: diana.szanto@artemisszio.hu 